\title{
Studies on Effect of Organic Treatments and Spacing on Growth and Yield Parameters of Kalmegh (Andrographis paniculata) var. CIM - Megha
}

\author{
M. Chandana ${ }^{1 *}$, Veena Joshi ${ }^{2}$, D. Lakshminarayana ${ }^{3}$ and D. Vijaya ${ }^{4}$ \\ ${ }^{1}$ Department of Plantation, Spices, Medicinal and Aromatic Crops, ${ }^{2}$ Department of Fruit \\ Science, ${ }^{3}$ Department of Horticulture, College of Horticulture, Rajendranagar, \\ SKLTSHU, Mulugu, Siddipet, India \\ ${ }^{4}$ Department of Soil Science and Analytical Chemistry, Grape Research Station, \\ SKLTSHU, India \\ *Corresponding author
}

\section{A B S T R A C T}

Keywords

Kalmegh, Organic treatments, AMC (Arka Microbial Consortium), Fresh weight, Dry weight, Growth and yield

Article Info

Accepted: 17 October 2020 Available Online: 10 November 2020
A field experiment conducted on the effect of organic treatments and spacing on growth and yield parameters of kalmegh under rabi season 2017-18 at college of Horticulture, Rajendranagar revealed that interaction between organic treatments and spacing significantly influenced growth and yield parameters. The treatment $\mathrm{M}_{1} \mathrm{~S}_{1}-\mathrm{FYM} 30 \mathrm{t} / \mathrm{ha}+$ AMC $(7.5 \mathrm{l} / \mathrm{ha})$ with spacing $\mathrm{S}_{1}(15 \times 15 \mathrm{~cm})$ recorded maximum plant height $(45.64 \mathrm{~cm})$ at harvest, followed by $\mathrm{M}_{3} \mathrm{~S}_{3}$ - Neem cake $7.5 \mathrm{t} / \mathrm{ha}+$ AMC $7.5 \mathrm{l} / \mathrm{ha}$ with spacing $\mathrm{S}_{3}(30 \times 45$ $\mathrm{cm})$. Minimum was recorded in $\mathrm{M}_{5} \mathrm{~S}_{3}-$ control at spacing $\left(\mathrm{S}_{3^{-}} 30 \mathrm{x} 45 \mathrm{~cm}\right)$. The treatment $\mathrm{M}_{2} \mathrm{~S}_{3}$-Vermicompost $6 \mathrm{t} / \mathrm{ha}+\operatorname{AMC}(7.5 \mathrm{l} / \mathrm{ha})$ with spacing $\mathrm{S}_{3}(30 \mathrm{x} 45 \mathrm{~cm})$ recorded maximum stem diameter $(3.43 \mathrm{~mm})$, followed by $\mathrm{M}_{3} \mathrm{~S}_{3}$ - Neem cake $7.5 \mathrm{t} / \mathrm{ha}+$ AMC 7.5 $1 /$ ha at spacing $S_{3}(30 \times 45 \mathrm{~cm})$. Minimum was recorded in the treatment $M_{5} S_{1}$ - Control with spacing $S_{1}(15 \times 15 \mathrm{~cm})$. The treatment $M_{1} S_{3}-F Y M(30 \mathrm{t} / \mathrm{ha})+\operatorname{AMC}(7.5 \mathrm{l} / \mathrm{ha})$ with spacing $S_{3}(30 \times 45 \mathrm{~cm})$ recorded maximum fresh weight of leaves per plant $(60.63 \mathrm{~g})$, dry weight of leaves per plant (30.26 g), at harvest, followed by the treatment $\mathrm{M}_{3} \mathrm{~S}_{3}$ whereas minimum was recorded in the treatment $M_{5} S_{1}$. The treatment $M_{1} S_{1}-(F Y M(30 t / h a)+$ AMC $(7.5 \mathrm{l} / \mathrm{ha})$ with spacing $\mathrm{S}_{1}(15 \times 15 \mathrm{~cm})$ recorded maximum fresh herb yield per plot $(3.12 \mathrm{~kg})$, dry herb yield per plot $(1.56 \mathrm{~kg})$, at harvest, followed by $\mathrm{M}_{3} \mathrm{~S}_{1}$ - Neem cake (7.5 $\mathrm{t} / \mathrm{ha})+\operatorname{AMC}(7.5 \mathrm{l} / \mathrm{ha})$ with spacing $\mathrm{S}_{1}(15 \mathrm{x} 15 \mathrm{~cm})$. Minimum was recorded in the treatment $\mathrm{M}_{5} \mathrm{~S}_{3}$ - Control with spacing $\mathrm{S}_{3}(30 \mathrm{x} 45 \mathrm{~cm})$.

\section{Introduction}

Kalmegh is a bitter annual herb (perennial, if maintained), erect, $50 \mathrm{~cm}$ to $1 \mathrm{~m}$. in height, stem quadrangular, much branched; leaves opposite, short petioled, flowers in racemes, fruit capsule, linear, oblong or elliptic; seeds about 12 in number, subquadrate, brownish or creamy yellow. Kalmegh is one of the important ingredients in various ayurvedic preparations used for fever and liver disease, which are commonly used by ayurvedic physicians. The herb is having a preventive effect from many diseases, due to its powerful 
immune strengthening benefits. The entire plant is used to treat snake bite. The hot water extract of the whole plant is used for acute jaundice. The decoction of the dried leaf is used against high blood pressure. The plant has properties like laxative, antipyretic, antiinflammatory, anti-viral, anti-malarial, anticancer (Kumar et al., 2004, Shen et al., 2002). Calabrese et al., (2000) has conducted a trial on HIV patients and found effective.

In the present content of rapid civilization, global warming, climate change, indiscriminate use of synthetic fertilizers and pesticides, sustainable production of agricultural crops is the prime objectives of agricultural researchers and policy makers. Organic production and integrated use of benefits are the key issues of today crop production.

For maintaining optimum productivity of the land and building up of soil fertility, the use of organic manures along with biofertilizers (Arka Microbial Consortium - AMC) to crops has been suggested. It is a well known fact that the availability of organic manures is very much limited in the present day agriculture (Annadurai et al., 2001).

Spacing is an important factor for better growth and yield of the plant. Optimum number of plants is required per unit area to utilize efficiently the available production factors such as water, nutrient, light and $\mathrm{CO}_{2}$.

\section{Materials and Methods}

The field experiment was conducted at College of Horticulture, Rajendranagar during rabi 2017-18. The soil type was loamy sand having $\mathrm{pH} 6, \mathrm{EC} 0.06 \mathrm{dSm}^{-1}$, low in available $\mathrm{N}\left(175.61 \mathrm{~kg} \mathrm{ha}^{-1}\right)$, low in available $\mathrm{P}(7.77$ $\mathrm{kg} \mathrm{ha}{ }^{-1}$ ) and medium in available potash $\left(182.56 \mathrm{~kg} \mathrm{ha}^{-1}\right)$. The experiment was laid out in Factorial randomized block design (FRBD) in three replications with 15 treatment combinations comprised of five levels of organic treatments viz., $\mathrm{M}_{1}-\mathrm{FYM}(30 \mathrm{t} / \mathrm{ha})+$ $\operatorname{AMC}\left(7.5\right.$ l/ha), $\mathrm{M}_{2}$ - Vermicompost (6t/ha) + $\operatorname{AMC}\left(7.5\right.$ 1/ha), $\mathrm{M}_{3}-$ Neem cake $(7.5 \mathrm{t} / \mathrm{ha})+$ AMC (7.5 1/ha), $\mathrm{M}_{4}$ - Sheep manure (10t/ha) + AMC (7.5 1/ha), $\mathrm{M}_{5}$ - Control and three levels of spacing viz., $\mathrm{S}_{1}-15 \times 15 \mathrm{~cm}, \mathrm{~S}_{2}-$ $30 \times 30 \mathrm{~cm}, \mathrm{~S}_{3}-30 \times 45 \mathrm{~cm}$.

\section{Results and Discussion}

\section{Plant height (cm)}

Interaction between organic treatments and spacing found to be non significant effect on plant height at harvest (Fig. 1 and Table 1).

\section{Stem diameter $(\mathbf{m m})$}

Interaction between organic treatments and spacing had significant effect on stem diameter at Harvest. $\mathrm{M}_{2} \mathrm{~S}_{3}$ Vermicompost (6 $\mathrm{t} / \mathrm{ha})+\operatorname{AMC}(7.5 \mathrm{l} / \mathrm{ha})$ with Spacing $\mathrm{S}_{3} 30 \mathrm{x}$ $45 \mathrm{~cm}$ recorded maximum stem diameter (3.43mm) followed by $\mathrm{M}_{3} \mathrm{~S}_{3}$ Neem cake (7.5 t/ha) + AMC (7.5 1/ha) with spacing $S_{3} 30 x$ $45 \mathrm{~cm}(3.27 \mathrm{~mm})$ which were remained on par. $\mathrm{M}_{5} \mathrm{~S}_{1}$ Control with spacing $\mathrm{S}_{1}-15 \times 15 \mathrm{~cm}$ $(1.02 \mathrm{~mm})$ recorded minimum stem diameter among all the interactions.

Incorporation of vermicompost promotes maximum stem diameter which might be due to the presence of plant growth promoters like auxins and cytokinins in vermicompost, which are responsible for cell division and cell elongation (Prabu and Shakila, 2013).

\section{Number of primary branches}

Interaction between organic treatments and spacing had significant effect on number of primary branches at harvest. Among all the interactions, $\mathrm{M}_{3} \mathrm{~S}_{3}$ Neem cake (7.5 t/ha) + AMC (7.5 1/ha) with spacing $S_{3} 30 \times 45 \mathrm{~cm}$ 
recorded maximum number of primary branches (17.23) followed by $\mathrm{M}_{1} \mathrm{~S}_{3}$ (16.63). $\mathrm{M}_{2} \mathrm{~S}_{3}$ Vermicompost (6 t/ha) + AMC (7.5 1/ha) with Spacing $S_{3} 30 \times 45 \mathrm{~cm}(16.16)$, $\mathrm{M}_{4} \mathrm{~S}_{3}$ Sheep manure (10 t/ha) + AMC (7.5 1/ha) with spacing $S_{3} 30 \times 45 \mathrm{~cm}(13.60)$ which were remained at par. Minimum number of primary branches was recorded in $\mathrm{M}_{5} \mathrm{~S}_{1}$ Control with spacing $\mathrm{S}_{1}-15 \times 15 \mathrm{~cm}$ (6.01).

Table.1 Effect of organic treatments and spacing on growth and yield parameters of kalmegh var. CIM-Megha at harvest

\begin{tabular}{|c|c|c|c|c|c|c|c|c|c|c|}
\hline Treatments & $\begin{array}{c}\text { Plant } \\
\text { height } \\
\text { (cm) }\end{array}$ & $\begin{array}{c}\text { Stem } \\
\text { diameter } \\
(\mathbf{m m})\end{array}$ & $\begin{array}{c}\text { No. of } \\
\text { primary } \\
\text { branches }\end{array}$ & $\begin{array}{c}\text { No. of } \\
\text { secondary } \\
\text { branches }\end{array}$ & $\begin{array}{l}\text { Leaf } \\
\text { area } \\
\left(\mathrm{cm}^{2}\right)\end{array}$ & $\begin{array}{c}\text { Crop } \\
\text { growth } \\
\text { rate } \\
\left(\mathrm{g} / \mathrm{day} / \mathbf{m}^{2}\right)\end{array}$ & $\begin{array}{c}\text { Fresh } \\
\text { weight of } \\
\text { leaves per } \\
\text { plant (g) }\end{array}$ & $\begin{array}{c}\text { Dry } \\
\text { weight } \\
\text { of leaves } \\
\text { per } \\
\text { plant (g) }\end{array}$ & $\begin{array}{c}\text { Fresh } \\
\text { herb } \\
\text { yield per } \\
\text { plot (kg) }\end{array}$ & $\begin{array}{c}\text { Dry } \\
\text { herb } \\
\text { yield } \\
\text { per plot } \\
\text { (kg) }\end{array}$ \\
\hline $\mathbf{M}_{1} \mathbf{S}_{1}$ & 45.64 & 1.04 & 8.01 & 2.41 & 653.90 & 1.87 & 32.39 & 18.16 & 3.12 & 1.56 \\
\hline $\mathbf{M}_{1} \mathbf{S}_{2}$ & 36.77 & 1.66 & 12.60 & 3.33 & 683.60 & 2.53 & 38.08 & 19.36 & 1.86 & 0.93 \\
\hline $\mathbf{M}_{1} \mathbf{S}_{3}$ & 33.56 & 2.66 & 16.63 & 5.57 & 890.60 & 7.14 & 60.63 & 30.26 & 1.46 & 0.73 \\
\hline $\mathrm{M}_{2} \mathrm{~S}_{1}$ & 40.73 & 1.42 & 7.86 & 2.39 & 635.40 & 1.26 & 31.57 & 16.07 & 2.43 & 1.21 \\
\hline $\mathbf{M}_{2} \mathbf{S}_{2}$ & 34.66 & 2.20 & 12.01 & 3.34 & 669.40 & 2.16 & 36.70 & 18.62 & 1.75 & 0.88 \\
\hline $\mathrm{M}_{2} \mathrm{~S}_{3}$ & 27.33 & 3.43 & 16.16 & 5.01 & 714.00 & 5.09 & 58.14 & 27.72 & 1.34 & 0.71 \\
\hline$M_{3} S_{1}$ & 40.95 & 1.34 & 8.30 & 2.61 & 645.30 & 1.36 & 31.95 & 17.16 & 2.96 & 1.48 \\
\hline $\mathbf{M}_{3} \mathbf{S}_{2}$ & 36.57 & 2.06 & 12.79 & 3.48 & 670.20 & 2.36 & 37.34 & 19.21 & 1.79 & 0.90 \\
\hline $\mathbf{M}_{3} \mathbf{S}_{3}$ & 32.75 & 3.27 & 17.23 & 5.78 & 788.10 & 6.31 & 59.43 & 29.04 & 1.38 & 0.73 \\
\hline $\mathbf{M}_{4} \mathbf{S}_{1}$ & 38.95 & 1.03 & 6.84 & 2.53 & 629.10 & 1.26 & 31.51 & 14.93 & 1.91 & 0.95 \\
\hline $\mathbf{M}_{4} \mathbf{S}_{2}$ & 33.74 & 1.57 & 7.02 & 3.03 & 668.90 & 1.96 & 36.55 & 15.63 & 1.63 & 0.82 \\
\hline $\mathbf{M}_{4} \mathbf{S}_{3}$ & 25.84 & 2.50 & 13.60 & 4.02 & 701.40 & 2.93 & 56.12 & 26.44 & 1.28 & 0.64 \\
\hline $\mathrm{M}_{5} \mathrm{~S}_{1}$ & 37.57 & 1.02 & 6.01 & 2.25 & 586.70 & 0.97 & 30.70 & 13.53 & 1.64 & 0.82 \\
\hline $\mathbf{M}_{5} \mathbf{S}_{2}$ & 28.23 & 1.24 & 6.78 & 3.02 & 667.20 & 1.93 & 35.34 & 14.82 & 1.45 & 0.68 \\
\hline $\mathbf{M}_{5} \mathrm{~S}_{3}$ & 25.83 & 2.34 & 13.46 & 3.62 & 684.20 & 2.52 & 54.74 & 24.54 & 1.22 & 0.61 \\
\hline S.Em \pm & 1.60 & 0.04 & 0.36 & 0.20 & 7.38 & 0.20 & 1.55 & 0.29 & 0.02 & 0.04 \\
\hline C.D & N.S & 0.13 & 1.06 & 0.58 & 21.39 & 0.59 & N.S & 0.84 & 0.70 & 0.10 \\
\hline
\end{tabular}

Fig.1 Effect of organic treatments and spacing on growth parameters of kalmegh var. CIM-Megha at harvest

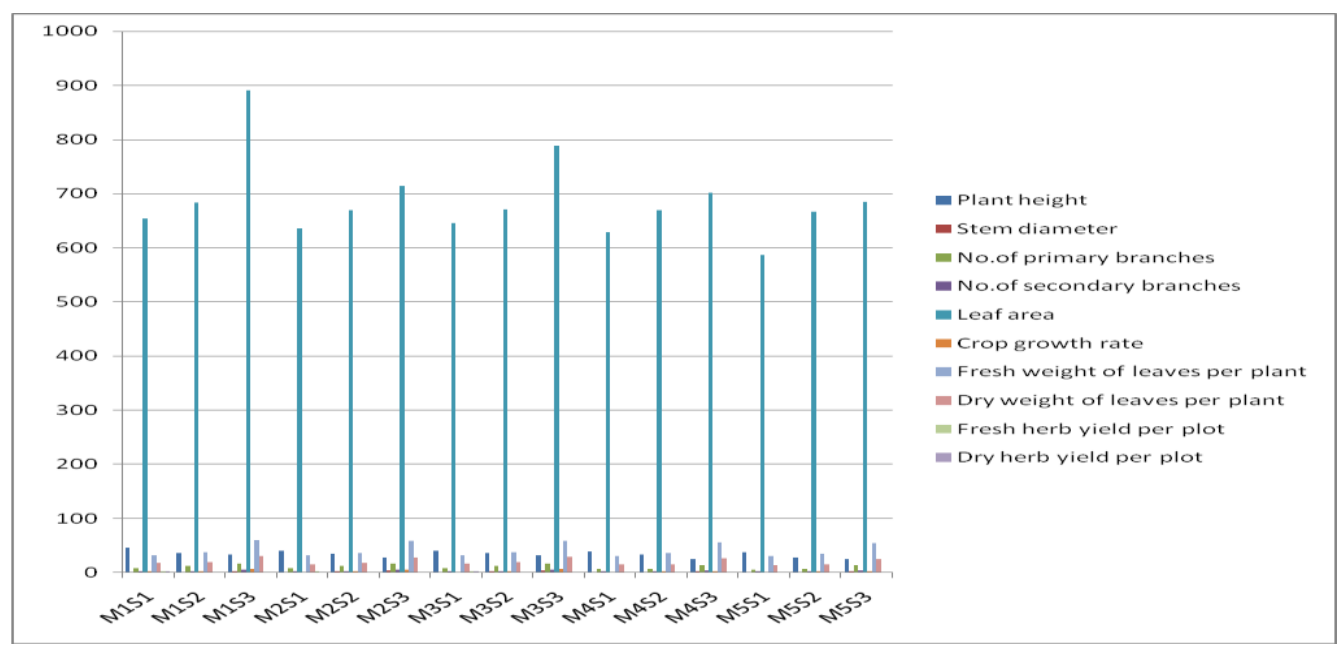


Increased number of branches was noticed in bio-fertilizers treatments could be attributed to activation of bio-active substances in plants due to the application of bio-fertilizers, which in the turn would have increased the availability of nutrients. Similar observations were recorded by Ajimuddin et al., (2005) in sweet basil.

Kumar et al., (2010) reported that maximum number of primary branches from wider spacing crop in kalmegh. The closer spacing $(15 \times 15 \mathrm{~cm})$ recorded the minimum number of primary branches per plant might be due to overcrowding and competition for sunlight, nutrients and air.

\section{Number of secondary branches}

Interaction between organic treatments and spacing had significant effect on number of secondary branches at harvest. $\mathrm{M}_{3} \mathrm{~S}_{3}$ Neem cake (7.5 t/ha) + AMC (7.5 1/ha) with spacing $\mathrm{S}_{3} 30 \times 45 \mathrm{~cm}$ recorded maximum number of secondary branches (5.78) followed by $\mathrm{M}_{1} \mathrm{~S}_{3}$ FYM (30 t/ha) + AMC (7.5 1/ha) with spacing $\mathrm{S}_{3} 30 \times 45 \mathrm{~cm}$ (5.57), $\mathrm{M}_{2} \mathrm{~S}_{3}$ Vermicompost (6 t/ha) + AMC (7.5 1/ha) with Spacing $S_{3} 30 x$ $45 \mathrm{~cm}$ (5.01) and were at par. Minimum number of secondary branches was recorded in $\mathrm{M}_{5} \mathrm{~S}_{1}$ Control with spacing $\mathrm{S}_{1}-15 \times 15 \mathrm{~cm}$ (2.25).

Number of secondary branches was found to be maximum with application of organic manures along with biofertilizers like azatobacter, phosphorous solubilizing bacteria and arbuscular mychorriza fungi independently or in combination enhances the $\mathrm{N}$ and $\mathrm{P}$ status respectively, which assisted the host plant to promote growth (Khaliq et al., 1997) in mentha spp., (Nath et al., 2000) Coleus, (Mohanchandra 2003) Solanum nigrum, (Ramesh babu. 1996). Wider spacing promotes branching in mint, because of exposure of the plant to light, which affected the plants to promote maximum number of secondary branches. (Salim et al., 2014)

\section{Leaf area $\left(\mathrm{cm}^{2}\right)$}

Interaction between organic treatments and spacing had significant effect on leaf area at Harvest. Among all the interactions $\mathrm{M}_{1} \mathrm{~S}_{3}$ FYM (30 t/ha) + AMC (7.5 1/ha) with spacing $\mathrm{S}_{3}(30 \times 45 \mathrm{~cm})$ recorded maximum leaf area (890.60) followed by $\mathrm{M}_{3} \mathrm{~S}_{3}$ Neem cake (7.5 t/ha) + AMC (7.5 1/ha) with spacing $S_{3} 30 \mathrm{x}$ $45 \mathrm{~cm}$ (788.10). Minimum leaf area was recorded in $\mathrm{M}_{5} \mathrm{~S}_{1}$ Control with spacing $\mathrm{S}_{1}-15$ x $15 \mathrm{~cm}$ (586.70).

In addition to mineralization and long term availability of nutrients by FYM, by the application of AMC might be the reason to cause increase in the length and breadth of the leaves leading to increased leaf area (Manjunatha et al., 2002). Light is important source of photosynthesis for plant growth, wider spaced plant get proper light intensity and nutrient as compare to the closely spaced plant So, maximum leaf area recorded under wider spacing. Similar results have been reported by Kahsay et al., (2014) who found that wider spaced plant get more leaf area.

\section{Crop growth rate}

Interaction between organic treatments and spacing had significant effect on crop growth rate at Harvest. Among all the interactions $\mathrm{M}_{1} \mathrm{~S}_{3}-\mathrm{FYM}(30 \mathrm{t} / \mathrm{ha})+\mathrm{AMC}(7.5 \mathrm{l} / \mathrm{ha})$ with spacing $\mathrm{S}_{3}(30 \mathrm{x} \quad 45 \mathrm{~cm})$ recorded the maximum crop growth rate (7.14) followed by $\mathrm{M}_{3} \mathrm{~S}_{3}-$ Neem cake (7.5 t/ha) + AMC (7.5 1/ha) with spacing $S_{3} 30 \times 45 \mathrm{~cm}$ (6.31). Minimum crop growth rate was observed in $\mathrm{M}_{5} \mathrm{~S}_{1}$ Control with spacing $\mathrm{S}_{1}-15 \times 15 \mathrm{~cm}$ (0.97).

The increasing crop growth rate due to application of FYM and biofertilizers may be 
due to the compensation with growth of number of plants per unit area by efficient utilization of available resources viz., nutrients, water, light and space and having comparatively less competition between intra and inter row spacing resulting optimum crop growth rate under wider spacing. The same results have been supported by various workers (Khanda and Mishra, 1999; Santhi and Vijayakumar, 1997, and Pareek et al., 1991).

\section{Fresh weight of leaves per plant}

Interaction between organic treatments and spacing did not exhibit any significant effect on fresh weight of leaves at Harvest.

\section{Dry weight of leaves per plant}

Interaction between organic treatments and spacing had significant effect on dry weight of leaves at Harvest. Among all the interactions $\mathrm{M}_{1} \mathrm{~S}_{3} \mathrm{FYM}$ (30 t/ha) + AMC (7.5 1/ha) with spacing $S_{3}(30 \times 45 \mathrm{~cm})$ recorded the maximum dry weight of leaves (30.26) followed by $\mathrm{M}_{3} \mathrm{~S}_{3}$ Neem cake (7.5 t/ha) + AMC $(7.5 \mathrm{l} / \mathrm{ha})$ with spacing $\mathrm{S}_{3} 30 \times 45 \mathrm{~cm}$ (29.04). Minimum dry weight of leaves was observed in $\mathrm{M}_{5} \mathrm{~S}_{1}$ Control with spacing $\mathrm{S}_{1}-15$ $\mathrm{x} 15 \mathrm{~cm}$ (13.53).

The highest dry weight per plant could be attributed to the promotion of growth and yield attributes due to greater uptake of nutrients into the plant system under the influence of biofertilizers. These are similar to the findings of Mahendran and Kumar (1998) in potato, Mahantesh (2002) in onion. The increasing dried leaf yield may be due to the compensation with growth of number of plants per unit area by efficient utilization of available resources. The same results have been supported by various workers (Khanda and Mishra,1999).

\section{Fresh herb yield per plot (kg)}

Interaction between organic treatments and spacing had significant effect on fresh herb yield per plot at Harvest. Among all the interactions $\mathrm{M}_{1} \mathrm{~S}_{1}-\mathrm{FYM}(30 \mathrm{t} / \mathrm{ha})+\mathrm{AMC} 7.5$ 1/ha with spacing $S_{1}-15 \times 15 \mathrm{~cm}$ recorded the maximum (3.12) followed by $\mathrm{M}_{3} \mathrm{~S}_{1}$ - Neem cake $7.5 \mathrm{t} / \mathrm{ha}+$ AMC 7.5 1/ha with spacing $S_{1}$ - 15 x $15 \mathrm{~cm}$ (2.96). Minimum fresh herb yield per plot was observed in $\mathrm{M}_{5} \mathrm{~S}_{3}$ - Control with spacing $S_{3}-30 \times 45 \mathrm{~cm}$ (1.22).

The application of organic manures before planting Mentha longifolia plants provide a beneficial effects on plant growth, due to their availability to supply macro and micro nutrients in available forms and improving soil structure (Dauda et al., 2008) and microbial biomass (Dhull et al., 2004). Among different spacing levels, more number of plants per unit area was observed under 15 $\mathrm{x} 15 \mathrm{~cm}$ spacing compared to other spacings. Such a phenomenon of higher yield at closer spacing has also been reported by Singh and Nand (1979) in Mentha spicata.

\section{Dry herb yield per plot (Kg)}

Interaction between organic treatments and spacing had significant effect on dry herb yield per plot at Harvest. Among all the interactions $\mathrm{M}_{1} \mathrm{~S}_{1}-\mathrm{FYM} 30 \mathrm{t} / \mathrm{ha}+\mathrm{AMC} 7.5$ 1/ha with spacing $S_{1}-15 \times 15 \mathrm{~cm}$ recorded the maximum (1.56) followed by $\mathrm{M}_{3} \mathrm{~S}_{1}$ - Neem cake 7.5 t/ha + AMC 7.5 1/ha with spacing $S_{1^{-}}$ $15 \times 15 \mathrm{~cm}$ (1.48). Minimum dry herb yield per plot was observed in $\mathrm{M}_{5} \mathrm{~S}_{3}$ Control with spacing $S_{3}-30 \times 45 \mathrm{~cm}(0.61)$.

Growing of kalmegh at closer spacing is suggested for obtaining maximum dry biomass yield (Singh et al., 2011).

In conclusion the application of FYM (30 t/ha) + AMC (7.5 1/ha) can be recommended 
for obtaining maximum growth and yield parameters. Spacing of $15 \times 15 \mathrm{~cm}$ can be recommended for higher herb yield and spacing of $30 \times 45 \mathrm{~cm}$ can be recommended for maximum growth parameters.

\section{References}

Ajimuddin, Shahram Sharafzadeh., and Mahdi zare 2005. Effect of biofertilizers on growth, essential oil and nutrients uptake of sweet basil. Advances in Environmental Biology. 5(4): 692-695.

Annadurai, K, Kavimani, R, Masilamani, P., and Rangaraju, G. 2001. Controlled application of treated distillery effluent (TDE) and organic amendments on soil fertility status and rice yield. Proc: Natl. Seminar on use of poor quality water and sugar industrial effluents in agriculture, held at ADAC \& RI, Tiruchirapalli, p.88.

Calabrese, C.S.H, Berman, J.G, Babish, X.M.A, Shinto, L.M.. Dorr, K. Wells, Werner, C.A., and Standish, L.J. 2000. A phase I trial of andrographolide in HIV positive patients and normal volunteers. Phytothery. Res. 14(5): 333338.

Dauda, S.N, Ajayi, F.A., and Ndor, E. 2008. Growth and yield of water melon (Citrullus lanatus) as affected by poultry manure application. Journal of Agriculture and Social Sciences. 4: 121124.

Dhull, S, Goyal, S, Kapoor, K., and Mundra, M. 2004. Microbial biomass carbon and microbial activities of soils receiving chemical fertilizers and organic amendments. Archives of Agronomy and Soil Science. 50(6): 641-647.

Kahsay, Y, Belew, D, Abay, F. 2014. Effect of intra-row spacing on plant growth and yield of onion Varieties (Allium cepa L.). African Journal of
Agricultural Research. 9(10): 931-940

Khaliq, A., and Janardhana, K.K. 1997. Influence of Vesicular Arbuscular Mycorrhizal Fungi on the Productivity of Cultivated Mints. J. Med. Aroma. Pl. Sci. 19; 7-10.

Khanda, C.M., and Mishra, P.K. 1999. Effect of plant density and nitrogen fertilization on growth and yield of rice bean (Vigna umbellata). Indian J. Agron.43 (4): 700-703.

Kumar R.A, Sridevi, K, Kumar, N.V, Nanduri. S., and Rajagopa, S. 2004. Anticancer and Immune stimulatory compounds from Andrographis paniculata. J.Etanopharma. 92(2-3): 291-295.

Kumar, K, Choudhary, H.P, Awasthi, U.D., and Sharma, D.C. 2010. Impact of plant density and sowing on growth, yield and Andrographolide content of Kalmegh (Andrographis paniculata Nees). Society for Recent Development in Agriculture Prog. Agric. 10 (1): 56-59.

Mahantesh, B., 2002, Evaluation on onion varieties / hybrids and effect of biofertilizers with levels of NPK on growth, yield and quality of onion (cv. Bellary Red) in central dry zone of Karnataka. Ph.D. Thesis, Univ. Agric. Sci., Bangalore (India).

Mahendran, P.P., and Kumar, N. 1998. Effect of biofertilizers on tuber yield and certain quality parameters of potato cv. Kufri Jyoti. South Indian Hort., 46(1\&2): 97-98.

Manjunatha, R, Farooqi, A.A, Vasundhara, M., and Srinivasappa, K.N. 2002. Effect of biofertilizers on growth, yield and essential oil content in patchouli (Pogestemon cablin Pellet.). Indian Perfumer. 46(2): 97-104

Mohanchandra, C.N. 2003. Effect of Biofertilizers on Growth, Yield and Alkaloid Content in Makoi (Solanum Nigrum). M.Sc. (Hort.) Thesis, 
University of Agricultural Sciences, Bangalore.

Nath, B., and Korla, B.N. 2000. Studies on Effect of Bio-Fertilizers in Ginger. Indian J. Hort. 57 (2) 160-171.

Pareek, S.K, Saxena, R.K, Kidwal, M.A., and Gupta, R. 1991. Effect of sowing date, stage of harvest and spacing on henbane crop. Indian J. Agron. 36(2): 247-250.

Prabu, M., and Shakila, A. 2013. Studies on organic nutrition in growth and yield of Japanese mint (Mentha arvensis L.) Asian journal of horticulture. 8: 126128.

Ramesh Babu, T.I. 1996. Nutritional Studies on Ashwagandha. M.Sc. (Hort.) Thesis Submitted to Horticultural College and Research Institute, Periyakulam.

Salim, E.A, Hassan, G.M.E., and Khalid, H.E.S. 2014. Effect of Spacing and Seasonal Variation on Growth Parameters, Yield and Oil Content of Mint Plants. Journal of forest products \& industries. 3(2): 71-74.
Santhi, V.P., and Vijayakumar, M. 1997. Yield and yield attributing parameters as influenced by spacing in palmarosa (Cymbopogon martini Var. Motia). South Indian J. Hort. 45 (3\&4):148150.

Shen, Y.C, Chen, C.F, Chiou, W.F. 2002. Andrographolide prevents oxygen radical production by human neutrophils: possible mechanism(s) involved in its antiinflammatory effect. Br. J. Pharmacol.135: 399-406.

Singh, H.P., and Singh, A.K. 2011.Growth behavior, biomass and diterpenoid lactones production in Kalmegh (Andrographis Paniculata.) strains at different population densities. Agricultural Journal. 6(3): 115-118.

Singh, N. P, Nand, K. 1979. Influence of planting time and row spacing on the yield spearmint. Indian Perfumer. 23(1):53-54.

\section{How to cite this article:}

Chandana, M., Veena Joshi, D. Lakshminarayana and Vijaya, D. 2020. Studies on Effect of Organic Treatments and Spacing on Growth and Yield Parameters of Kalmegh (Andrographis paniculata) var. CIM - Megha. Int.J.Curr.Microbiol.App.Sci. 9(11): 2375-2381. doi: https://doi.org/10.20546/ijcmas.2020.911.284 